\title{
BRIEF COMMUNICATION Female gender but not season of birth is associated with mood seasonality in a near-equatorial Brazilian city
}

\author{
Sexo feminino, mas não época de nascimento, está \\ associado com alterações sazonais do humor em \\ uma cidade brasileira próxima ao Equador
}

Taciano L. Milfont', Benjamin A. Tilyard', Valdiney V. Gouveia², Lorenzo Tonetti ${ }^{3}$ Vincenzo Natale

\begin{abstract}
Objective: Studies conducted mainly in countries located in the Northern Hemisphere have shown that season of birth influences mood seasonality. Greater mood seasonality has been observed for individuals born during spring/summer months than those born during autumn/winter months. Expanding past research to the Southern Hemisphere, in this study we examine the influence of season of birth on mood seasonality in a sample of 1,247 healthy young Brazilians. Method: The Seasonal Pattern Assessment Questionnaire was used to compute a global seasonality score as a measure of mood seasonality in a cross-sectional study. Results: Analysis of covariance was conducted to examine the effects of month of birth and gender on mood seasonality, with age entered as a covariate. A main effect of gender was observed, $F(1,1197)=17.86, p<.01$; partial Eta-squared $=.02$, with mood seasonality being higher for females $(M=8)$ than for males $(M=7)$. Contradicting previous findings, no significant main effect for month of birth was observed, $F(1,1197)=0.65, p>.05$. Conclusion: The unexpected finding is tentatively explained by differences in geographic location and weather fluctuations between the sampling location in Brazil and other countries where season of birth has been found to influence mood seasonality. Additional studies with larger samples from the Southern Hemisphere are necessary to shed additional light on the possible significant influence of season of birth on mood.
\end{abstract}

\section{RESUMO}

Objetivo: Estudos realizados principalmente em países do Hemisfério Norte têm demonstrado que indivíduos nascidos durante os meses de primavera/verão tendem a apresentar maiores alterações sazonais do humor do que aqueles nascidos durante os meses de outono/inverno. Expandindo essas pesquisas para o Hemisfério Sul, o presente estudo examinou a relação entre época do nascimento e a flutuação sazonal do humor em uma amostra de 1.247 jovens brasileiros saudáveis de João Pessoa, Paraíba. Método: Uma versão traduzida do Seasonal Pattern Assessment Questionnaire (SPAQ) foi utilizada para calcular uma pontuação

1 Victoria University of Wellington, New Zealand.

2 Federal University of Paraiba (UFPB), Brazil.

Recebido em

$11 / 7 / 2012$

Aprovado em

3 Department of Psychology, University of Bologna, Bologna, Italy.

Address for correspondence: Taciano L. Milfont

School of Psychology, Victoria University of Wellington

P0 Box 600, Wellington, New Zealand 6001

Phone: +644 463-6398

Fax: $+644463-5402$

E-mail: taciano.milfont@vuw.ac.nz

Webpage: www.milfont.com 


\section{Palavras-chave}

Época de nascimento, humor sazonal, fotoperíodo, Brasil. global de alterações sazonais do humor em um estudo transversal. Resultados: Análise de covariância foi utilizada para examinar os efeitos de mês de nascimento e do sexo sobre o humor sazonal, com idade como covariável. Alterações de humor sazonal foram maiores para mulheres $(M=8)$ do que homens $(M=7), F(1,1197)=17,86, p<, 01$; parcial Eta-quadra$\mathrm{do}=0,02$. Contrariando achados anteriores, nenhum efeito significativo foi observado entre mês de nascimento e humor sasonal, $F(1,1197)=0,65, p>, 05$. Conclusão: Este achado inesperado é tentativamente explicado pelas diferenças na localização geográfica e nas flutuações climáticas entre o Brasil e os outros países descritos na literatura. Estudos adicionais com amostras maiores do Hemisfério Sul são necessários para lançar luz sobre a possível influência significativa da época de nascimento no humor.

\section{INTRODUCTION}

Previous research has reported a statistically significant influence of season of birth on factors such as brain tumour development ${ }^{1}$, handedness ${ }^{2}$, longevity ${ }^{3}$, personality ${ }^{4}$, and schizophrenia and bipolar disorder ${ }^{5}$. Does season of birth also have an influence on mood? The answer seems to be positive.

A study conducted in Vienna, Austria, reported that a greater number of outpatients with Seasonal Affective Disorder (SAD) between 1994 and 2003 were born during the months of April to September, which represents spring/summer months in Europe ${ }^{6}$. These findings suggest that season of birth may have a significant effect on the occurrence of mood disorders such as SAD, which is classed as a mood disorder characterised by the regular recurrence of depressive episodes during winter months or summer months (reverse $\mathrm{SAD})^{7}$. Although some treatments are successful (particularly bright-light therapy) ${ }^{8}$, there is still much to understand about the etiological source of this mood disorder. Understanding the potential influence of season of birth may be one step in this direction.

A recent study has found that mood seasonality seems to be modulated by season of birth among healthy university students 9 . Supporting a photoperiod-at-birth hypothesis, Italian and Spanish individuals born during spring or summer (long photoperiod) had significantly higher mood seasonality than people born during autumn or winter (short photoperiod). The same pattern of findings was observed in another study with a large sample of Italians in late childhood and adolescence (age ranging from 10 to 17 years), indicating that the significant effect of season of birth on mood seasonality is already present at a young age ${ }^{10}$.

Expanding these initial findings, a more recent study compared the influence of season of birth on mood among participants located in the Northern (Italy) and Southern Hemispheres (New Zealand) ${ }^{11}$. A significant overall month of birth effect was observed only for male participants (regardless of country), with those born in April or August having higher mood seasonality than those born in February. This and other studies have also observed significant gender differences, with female participants showing higher mood seasonality than males, ${ }^{9,11}$.
Due to the geographic location of the findings reviewed above, it would be necessary to test the robustness of these results using more samples from countries in the Southern Hemisphere. The current research examines the effect of birth season on mood seasonality in Brazil. Such research will shed additional light onto the relationship between season of birth and mood seasonality while considering the potential implications for the development of mood disorders such as SAD. Based on previous findings, it is expected that month of birth will also have a statistically significant effect on mood seasonality for the Brazilian participants, and that female participants will show higher mood seasonality.

\section{METHOD}

\section{Participants and measures}

The study was conducted with a sample of healthy individuals from the general population. All participants were recruited and tested in Joao Pessoa (latitude and longitude: $7^{\circ} 06^{\prime} \mathrm{S} ; 34^{\circ} 51^{\prime} \mathrm{W}$ ), which is the capital city of the Brazilian state of Paraiba. A total of 1,255 Brazilian-born participants took part in the study, but eight participants were excluded from the analyses because they did not report gender. From the usable sample of 1,247 participants, the majority were female $(810,65 \%)$, single at the time of the study $(75.5 \%)$, and were born in Joao Pessoa (630, 50.5\%; with an additional 336 participants born in the state of Paraiba). The age of the participants ranged from 16 to 90 years $(M=25.10$ years, SD = 8.80), and the average number of years living in Joao Pessoa was 17 years $(S D=10.47)$.

Participants completed the Seasonal Pattern Assessment Questionnaire (SPAQ) ${ }^{12}$, plus socio-demographic questions. The SPAQ is a retrospective self-report instrument designed to screen for $S A D$, and is the most widely used self-reporting questionnaire for normal and clinical seasonal mood variations. The SPAQ collects information about six aspects of everyday life: sleep length, social activity, mood (overall feeling of well being), weight, appetite, and energy level. Participants are asked to indicate how much they fluctuate on each of these dimensions throughout the year with the seasons, on 
a 5 -point scale (anchored by $0=$ no change to $4=$ extremely marked change). Combining the scores of these six dimensions provides a Global Seasonality Score (GSS; range 0-24). The SPAQ was translated into Brazilian-Portuguese by the first and third authors, who have expertise in validating psychological measures to the Brazilian context and across cultures.

\section{Procedure and data analysis}

The study was conducted in accordance with Resolution 196/96 of the Brazilian National Health Council, and all participants were informed about the anonymity and confidentiality of the survey. Participants were individually contacted at their home or in public places, and requested to collaborate with the study. Two-way ANCOVAs were conducted to examine the effects of month of birth and gender on mood seasonality, with age entered as a covariate. If significant results were observed, Tukey's post-hoc test for unequal samples was then performed. Statistical analyses were carried out using SPSS for Windows.

\section{RESULTS}

Table 1 reports the GSS scores by month and gender. Supporting predictions, a statistically significant (albeit small) main effect of gender was observed, $F(1,1197)=17.86, p<$ .01; partial Eta-squared $=.02$, with mood seasonality being higher for females $(M=8)$ than for males $(M=7)$. Contradicting predictions and previous findings, no statistically significant main effect for month of birth was observed ( $F[1$, 1197] $=0.65, p>$.05). Moreover, no statistically significant interaction was found between month of birth and gender, $F(11,1197)=0.97, p>.05$.

\section{DISCUSSION}

Season of birth has been shown to influence many factors, including mood. Higher mood seasonality has been observed in the Northern Hemisphere for individuals born during spring/summer months compared to those born during autumn/winter months ${ }^{9,10}$. The effect of month of birth on mood was also observed in a recent study involving participants from both hemispheres ${ }^{11}$. The present study contributed to this literature by examining the influence of season of birth on mood in another sample from a country in the Southern Hemisphere (Brazil).

In line with previous findings9,11, we observed a main effect for gender on mood seasonality. These congruent findings indicate that women tend to experience greater mood seasonality than men, and that the current treatments for sufferers of mood disorders (such as SAD) may have differing effects for men and women.
Table 1. Global Seasonality Score (GSS) by month and gender

\begin{tabular}{|c|c|c|c|c|}
\hline \multicolumn{5}{|c|}{ Brazil } \\
\hline Month & Gender & Mean & SD & N \\
\hline \multirow[t]{3}{*}{ January } & Female & 8.20 & 3.80 & 59 \\
\hline & Male & 7.07 & 4.55 & 44 \\
\hline & Total & 7.71 & 4.15 & 103 \\
\hline \multirow[t]{3}{*}{ February } & Female & 8.08 & 4.60 & 61 \\
\hline & Male & 7.48 & 4.10 & 25 \\
\hline & Total & 7.91 & 4.45 & 86 \\
\hline \multirow[t]{3}{*}{ March } & Female & 8.86 & 4.07 & 70 \\
\hline & Male & 5.86 & 2.81 & 43 \\
\hline & Total & 7.72 & 3.91 & 113 \\
\hline \multirow[t]{3}{*}{ April } & Female & 6.91 & 3.64 & 70 \\
\hline & Male & 6.74 & 4.13 & 34 \\
\hline & Total & 6.86 & 3.79 & 104 \\
\hline \multirow[t]{3}{*}{ May } & Female & 8.23 & 3.95 & 81 \\
\hline & Male & 7.91 & 3.87 & 42 \\
\hline & Total & 8.12 & 3.91 & 123 \\
\hline \multirow[t]{3}{*}{ June } & Female & 8.25 & 4.37 & 52 \\
\hline & Male & 7.45 & 4.13 & 29 \\
\hline & Total & 7.96 & 4.27 & 81 \\
\hline \multirow[t]{3}{*}{ July } & Female & 7.73 & 3.35 & 71 \\
\hline & Male & 7.47 & 4.22 & 45 \\
\hline & Total & 7.63 & 3.69 & 116 \\
\hline \multirow[t]{3}{*}{ August } & Female & 8.02 & 4.12 & 62 \\
\hline & Male & 7.10 & 4.04 & 31 \\
\hline & Total & 7.71 & 4.09 & 93 \\
\hline \multirow[t]{3}{*}{ September } & Female & 8.32 & 4.15 & 63 \\
\hline & Male & 7.00 & 3.69 & 41 \\
\hline & Total & 7.80 & 4.01 & 104 \\
\hline \multirow[t]{3}{*}{ October } & Female & 8.07 & 4.73 & 69 \\
\hline & Male & 7.03 & 3.36 & 36 \\
\hline & Total & 7.71 & 4.32 & 105 \\
\hline \multirow[t]{3}{*}{ November } & Female & 8.32 & 4.03 & 72 \\
\hline & Male & 6.42 & 3.73 & 24 \\
\hline & Total & 7.84 & 4.02 & 96 \\
\hline \multirow[t]{3}{*}{ December } & Female & 7.53 & 3.75 & 66 \\
\hline & Male & 6.62 & 4.18 & 32 \\
\hline & Total & 7.23 & 3.90 & 98 \\
\hline \multirow[t]{3}{*}{ Total } & Female & 8.04 & 4.05 & 796 \\
\hline & Male & 7.02 & 3.91 & 426 \\
\hline & Total & 7.68 & 4.03 & 1222 \\
\hline
\end{tabular}

However, there was no main effect of season of birth on mood seasonality for this Brazilian sample. One possible explanation for this unexpected finding is the country's geographic location with respect to the Equator. At $7^{\circ}$ South (based on the location of our data collection), the Brazilian data was very close to the Equator. In contrast, data collected in another country in the Southern Hemisphere (New Zealand) was from a location further away from the Equator (collected at $41^{\circ}$ South). Previous research has reported a significant influence of latitude on the occurrence of SADrelated symptoms. For example, one study investigated the occurrence of SAD in American research stations in Antarctica $^{13}$. The results from this study indicated that individuals are more likely to experience SAD symptoms in high latitude environments and that such symptoms become more pronounced as latitude increases. These findings have been 
matched in other studies based within the Arctic circle ${ }^{14}$. Further research has suggested that greater mental stress is experienced by individuals located at higher latitudes, characterised by extreme fluctuations in daylight ${ }^{15}$.

One additional explanation for the unexpected findings between the present study and previous findings is the extreme weather fluctuations more prominent within the other sampled countries (Italia, Spain and New Zealand) compared to Brazil. For example, New Zealand typically has colder temperatures throughout the year and longer periods of non-daylight hours compared to Brazil. This may help to explain why season of birth was not a statistically significant factor in this Brazil sample.

It is also worth noting that the pattern of findings for the New Zealand sample was inverse to the findings observed for countries in the Northern Hemisphere. While higher mood seasonality was observed for university students born during spring/summer months compared to those born during autumn/winter months in both Italy and Spain?, higher mood seasonality for New Zealand participants was observed for those born during a winter month (August) compared to a summer month (February) ${ }^{11}$. These patterns of findings may be due to a difference between participants born in the Northern and Southern Hemispheres. The available findings suggest that season of birth has a contrasting effect on individuals in the Southern Hemisphere compared to those located in the Northern Hemisphere.

\section{CONCLUSION}

To the best of our knowledge, this is the first study examining the influence of season of birth on mood seasonality in a Brazilian sample. Although the findings did not support the expected influence, this study contributes with the growing international literature on the topic. Findings also provide further support for previous observed gender differences, with women showing greater mood seasonality than men. Additional studies with larger samples from the Southern Hemisphere are necessary to fully understand the influence of season of birth on mood seasonality and this possible contrasting effect, while shedding additional light on the potential moderating effect of latitude. Understanding the potential influence of season of birth may be one step in understanding the etiological source of mood seasonality and disorders.

\section{INDIVIDUAL CONTRIBUTIONS}

T. L. Milfont and B. A. Tilyard conducted the statistical analyses and drafted the article. V. V. Gouveia supervised data collection. L. Tonetti and $\mathrm{V}$. Natale devised the research questions, and together with V. V. Gouveia provided statistical advice and oversight. All authors contributed to the interpretation of analyses, and to the critical revision of the article.

\section{CONFLICTS OF INTEREST}

The authors declare that they have no conflicts of interest with respect to their authorship or the publication of this article.

\section{ACKNOWLEDGMENTS}

We thank the individuals from Joao Pessoa, Brazil, who kindly agreed to take part in this study. The writing of this article was supported in part by a sabbatical grant awarded to T. L. Milfont by the Victoria University of Wellington.

\section{REFERENCES}

1. Brenner AV, Linet MS, Shapiro WR, Selker RG, Fine HA, Black PM, et al. Season of birth and risk of brain tumours in adults. Neurology. 2004;63:276-81.

2. Martin $M$, Jones GV. Handedness and season of birth: a gender-invariant relation. Cortex. 1999;35:123-8.

3. Moore SE, Cole TJ, Poskitt EME, Sonko BJ, Whitehead RG, McGregor IA, et al. Season of birth predicts mortality in rural Gambia. Nature. 1997;388:434.

4. Chotai J, Forsgren T, Nilsson L, Adolfsson R. Season of birth variations in the temperament and character inventory of personality in a general population. Neuropsychobiology. 2001;44:19-26.

5. Boyd JH, Pulver AE, Stewart W. Season of birth: schizophrenia and bipolar disorder. Schizophrenia Bull. 1986;12:173-88

6. Pjrek E, Winkler D, Heiden A, Praschak-Rieder N, Willeit M, Konstantinidis A, et al. Seasonality of birth in seasonal affective disorder. J Clin Psychiatry. 2004;65:1389-93.

7. Muscettola G, Barbato G, Ficca G, Beatrice M, Puca M, Aguglia E, et al. Seasonality of mood in Italy: role of latitude and socioeconomic factors. J Affect Disord. 1995;33:135-9.

8. Lewy AJ, Sack RL, Singer CM, White DM, Hoban TM. Winter depression and the phase-shift hypothesis for bright light's therapeutic effects: history and experimental evidence. In: Rosenthal NE, Blehar MC, editors. Season affective disorders and phototherapy. New York: Guilford Press; 1989.

9. Natale V, Adan A, Chotai J. Season of birth modulates mood seasonality in humans. Psychiatry Res. 2007;153:199-201.

10. Tonetti L, Fabbri M, Martoni M, Natale V. Season of birth and mood seasonality in late childhood and adolescence. Psychiatry Res. 2012;195:66-8.

11. Tonetti L, Milfont TL, Tilyard B, Natale V. Month of birth and mood seasonality: a comparison between countries in the northern and southern hemispheres. Psychiatry Clin Neurosci. [in press].

12. Rosenthal NE, Bradt GH, Wehr TA. Seasonal pattern assessment questionnaire (SPAQ). Bethesda, MD: National Institute of Mental Health; 1984.

13. Palinkas LA, Houseal M, Rosenthal NE. Subsyndromal seasonal affective disorder in Antarctica. J Nerv Ment Dis. 1996;184:530-4.

14. Haggarty JM, Cernovsky Z, Husni M, Minor K, Kermeen P, Merskey H. Seasonal affective disorder in an Arctic community. Acta Psychiatr Scand. 2008;105:378-384.

15. Hansen V, Jacobsen BK, Husby R. Mental distress during winter: an epidemiologic study of 7759 adults north of Arctic Circle. Acta Psychiatr Scand. 1991;84:137-41. 